\title{
Comparative Analysis of the Efficiency Penalty in Power Plants of Different Amine-Based Solvents for $\mathrm{CO}_{2}$ Capture
}

\author{
Luis M. Romeo,* Diego Minguell, Reza Shirmohammadi, and José M. Andrés
}

Cite This: https://dx.doi.org/10.1021/acs.iecr.0c01483

Read Online

ABSTRACT: Amine solvents are one of the main options for postcombustion $\mathrm{CO}_{2}$ capture applications. The main drawback of the carbon capture processes is the required energy to regenerate the solvent once it has reacted with the $\mathrm{CO}_{2}$. When applied to a power plant, the energy requirement has an important impact on the net efficiency of the overall system. Several solvents, i.e., monoethanolamine (MEA), diethanolamine (DEA), methyl diethanolamine (MDEA), and many others have been proposed to overcome this drawback. Regeneration temperature and heat duty reduction are considered to be the significant objectives. Moreover, enhancement of the amine's concentration and its working capacity without the impact on the other variables are important. In this work, different types of amines with a wide range of heat duty and regeneration temperatures under the same set of assumptions are calculated and

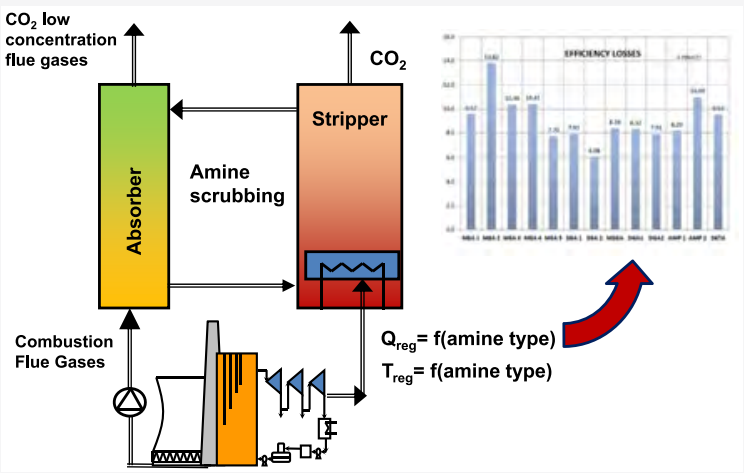
compared. The effect of both variables on the energy penalty caused by carbon capture is measured. A review of amines and their effects on the net efficiency of the overall system (power plant, chemical absorption, $\mathrm{CO}_{2}$ compression) are conducted and analyzed. As expected, the impact of heat duty is greater than the modification of regeneration temperature. The effect of reducing $1 \mathrm{GJ} /$ ton $\mathrm{CO}_{2}$ in the heat duty is similar to the effect of reducing the regeneration temperature from $40{ }^{\circ} \mathrm{C}$ to $25{ }^{\circ} \mathrm{C}$.

\section{INTRODUCTION}

The global climate policy is focused on the deployment of renewable technologies to fight against climate change caused by $\mathrm{CO}_{2}$ emissions. Nevertheless, some heavy industries are still dependent on the consumption of fossil fuels rather than electricity for their operation. Moreover, renewables are generally capital-intensive and, in some scenarios, their availability and accessibility reduces their competitiveness with fossil fuels. ${ }^{1}$ As a result, fossil fuels seemingly would still play an important role in the future energy mix of the world; therefore, nations should reconsider their climate policies and turn their attention toward $\mathrm{CO}_{2}$ capture and storage (CCS) technologies if they are inclined to attain a carbon-free and, more importantly, reliable energy system.

Chemical absorption based on amine solvents is the main technology for post-combustion $\mathrm{CO}_{2}$ capture. ${ }^{2}$ The technology has some drawbacks, such as giant energy consumption for regeneration of the $\mathrm{CO}_{2}$-loaded amine solution, degradation of the amine solvent, and equipment corrosion. ${ }^{3}$ But the energy consumption of regeneration is considered to be the major challenge, because it consumes more than $70 \%$ of the total operating costs of a $\mathrm{CO}_{2}$ capture plant. Consequently, the reduction in heat duty of regeneration should be the main priority for further development in amine-based $\mathrm{CO}_{2}$ capture technology. ${ }^{4}$
Several works in the literature have demonstrated, through techno-economic analysis, the improvement or advantages of using one specific solvent instead of, mainly, monoethanolamine (MEA). Nevertheless, MEA is the most-common, mostdeveloped, and most-demonstrated solvent for carbon capture. For example, an optimization and economic analysis for an amine-based acid gas capture unit using MEA and methyl diethanolamine (MDEA) has been reported. ${ }^{5}$ In that report, Aspen Plus software was utilized to demonstrate that the use of an MEA/MDEA mixture, in lieu of MEA, leads to a surge in $\mathrm{CO}_{2}$ removal rate and a reduction in energy penalty. For industrial applications, it has been highlighted, for a cement plant, that the total equipment cost and capital expenditure and the energy penalty of the AMP-PZ-MEA blend (where AMP represents 2amino-2-methyl-1-propanol and PZ represents piperazine) is lower, compared to the MEA. ${ }^{6}$ Furthermore, it was shown that the effect of a reduction in the percentage of $\mathrm{CO}_{2}$ captured in an industrial CCS plant integrated to the natural gas fired power

Received: March 24, 2020

Revised: May 5, 2020

Accepted: May 6, 2020

Published: May 6, 2020 
Table 1. Amines Used in This Work

\begin{tabular}{|c|c|c|}
\hline Acronym & Name & Chemical formula \\
\hline MEA & $\begin{array}{l}\text { Monoethanolamine } \\
\text { 2-aminoethanol }\end{array}$ & \\
\hline DEA & $\begin{array}{l}\text { Diethanolamine } \\
\text { bis(2-Hydroxyethyl)amine }\end{array}$ & \\
\hline MDEA & $\begin{array}{l}\text { Methyl diethanolamine } \\
\text { Bis(2-hydroxyethyl) methyl } \\
\text { amine }\end{array}$ & \\
\hline DGA & $\begin{array}{l}\text { Diglycolamine } \\
\text { 2-(2-aminoethoxy)ethanol }\end{array}$ & \\
\hline AMP & $\begin{array}{l}\text { Aminomethylpropanol } \\
\text { 2-amino-2-methyl-1- } \\
\text { propanol }\end{array}$ & \\
\hline DETA & $\begin{array}{l}\text { Diethyelenetriamine } \\
\text { 2,2'-Diaminodiethylamine }\end{array}$ & \\
\hline $\mathrm{NH} 3$ & Ammonia & $\mathrm{NH}_{3}$ \\
\hline
\end{tabular}

plant. The influence of the CCS plant on the efficiency of the power plant was analyzed. The efficiency of power plants declined from $33.22 \%$ to $32.86 \%$ by capturing $5 \%$ of the flue gas. ${ }^{7}$

It is more common in the literature to present comparisons between several solvents to prove that the improvement can be attributed to some specific variables. For energy regeneration, it has been shown that DEA had superiority over MEA for several configurations studied, in terms of total equivalent work and reboiler duty; ${ }^{8}$ amine-carbonate blend with 30 wt \% (MEA) experimentally needed $10 \%$ lower energy regeneration than MEA; ${ }^{9}$ or the use of triblend amines (MEA-MDEA-PZ) was an excellent approach for increasing $\mathrm{CO}_{2}$ desorption activity and extremely declining the energy penalty of amine-based $\mathrm{CO}_{2}$ capture systems. ${ }^{10} \mathrm{CO}_{2}$ absorption rate, ${ }^{1011}$ and high absorption and desorption efficiencies ${ }^{12}$ are other variables that have been used for comparison.

Despite all of the literature, there is a lack of literature to compare, energetically, the performance of different solvents under common assumptions. Some relevant attempts have been made using Aspen and multiobjective genetic algorithm optimization to select the best process design and operating conditions for MEA, diethanolamine (DEA), and AMP. ${ }^{13}$ Generally, most of the studies are specific for pilot plants and use ASPEN software for simulations. MEA with a heat consumption of $\sim 3.6-3.7 \mathrm{GJ} / \mathrm{tCO}_{2}$ is the most popular option used in these works ${ }^{81415} .16$ Different capture rates were reported in these studies, from $79.9 \%{ }^{8}$ to $86 \%{ }^{14} .{ }^{15}$ Studies also shows that there is room for improvements and the previous value of $3.6 \mathrm{GJ} / \mathrm{t} \mathrm{CO}_{2}$ could be reduced to $3.1 \mathrm{GJ} / \mathrm{t} \mathrm{CO}_{2}{ }^{16}$ They did not show any effect of this reduction on hypothetical power plant efficiency. The use of other solvents is not as numerous as MEA; for example, blended amines with a combination of mixtures of AMP and MDEA, using DEA and MEA as activating agents, has been also simulated for a $600 \mathrm{MWe}$ conventional coal-fired power plant ${ }^{17}$ or MEA, PZ, and PZ-MDEA blends for the flue gas from the Norcem Brevik cement plant. ${ }^{18}$ Results showed that the mixture of $5 \mathrm{wt} \% \mathrm{DEA}$ and $25 \mathrm{wt} \%$ AMP performed better than the other mixtures by obtaining heat consumptions of $3.03 \mathrm{GJ} / \mathrm{tCO}_{2}$. Similarly, ammonia, as a carbon dioxide solvent, has been compared and evaluated under optimum operating conditions that minimize the impact on the thermal performance of the regeneration, depending on the $\mathrm{CO}_{2}$ loading of the lean solution and the ammonia concentration. ${ }^{19}$
In this work, a comparative analysis, in terms of the efficiency penalty in power plants, is conducted for different amine-based solvents aimed at capturing $\mathrm{CO}_{2}$. First, a sensitivity analysis of the efficiency penalty, which is dependent on regeneration temperature and stripper heat duty, is presented. Then, a comparison of the impact of several amines with different energy requirements on the efficiency of the power plants, based on literature data, is presented. Note that, apart from the significant energy requirement, it is not the only variable to be considered when the amine is selected for $\mathrm{CO}_{2}$ capture. Operability, cost, maintenance, corrosive risk, etc. should be also considered.

\section{AMINE-BASED SOLVENTS FOR $\mathrm{CO}_{2}$ CAPTURE}

Several types of amines have been chosen for simulations (Table 1). Amines are organic compounds that can act as bases by protonation of the lone pair of electrons in the nitrogen atom. In the case of $\mathrm{CO}_{2}$ capture, a molecule of $\mathrm{H}_{2} \mathrm{O}$ is involved in the reaction leading to the formation of substituted ammonium bicarbonates:

$$
\mathrm{R}_{1} \mathrm{R}_{2} \mathrm{R}_{3} \mathrm{~N}+\mathrm{H}_{2} \mathrm{O}+\mathrm{CO}_{2} \rightarrow \mathrm{R}_{1} \mathrm{R}_{2} \mathrm{R}_{3} \mathrm{NH}^{+} \mathrm{HCO}_{3}^{-}
$$

Besides this general mechanism of reaction, ammonia and amines containing a hydrogen atom bonded to the nitrogen one-that is, primary and secondary amines-can react with $\mathrm{CO}_{2}$, forming substituted ammonium carbamates. The reaction proceeds in two steps:

$$
\begin{aligned}
& \mathrm{R}_{1} \mathrm{R}_{2} \mathrm{NH}+\mathrm{CO}_{2} \rightarrow \mathrm{R}_{1} \mathrm{R}_{2} \mathrm{NH}^{+} \mathrm{HCOO}^{-} \\
& \mathrm{R}_{1} \mathrm{R}_{2} \mathrm{NH}^{+} \mathrm{HCOO}^{-}+\mathrm{R}_{1} \mathrm{R}_{2} \mathrm{NH} \rightarrow \mathrm{R}_{1} \mathrm{R}_{2} \mathrm{NCOO}^{-}+\mathrm{R}_{1} \mathrm{R}_{2} \mathrm{NH}_{2}^{+}
\end{aligned}
$$

The first reaction involves a molecule of amine plus a molecule of $\mathrm{CO}_{2}$ to form a zwitterion that, subsequently, forms the substituted ammonium carbamate.

It can be seen from the reaction equations that absorption as bicarbonate requires one molecule of amine per molecule of $\mathrm{CO}_{2}$, while the formation of ammonium carbamate requires two molecules of amine per molecule of $\mathrm{CO}_{2}$. Despite the different loading of amine required, primary and secondary amines are mainly used because of the different kinetics of the reactions, with bicarbonate formation being much slower that carbamate formation. Work done in the capture of $\mathrm{CO}_{2}$ by different amines show that the reaction constants can vary from $7500 \mathrm{~m}^{3} / \mathrm{s} / \mathrm{kmol}$ for $\mathrm{MEA}^{20}$ to $1200 \mathrm{~m}^{3} / \mathrm{s} / \mathrm{kmol}$ for $\mathrm{DEA}^{21}$ and to 3.5 for MDEA. $^{22}$ A mixed primary-secondary amine, such as DETA, has 
a reaction constant of $47740 \mathrm{~m}^{3} / \mathrm{s} / \mathrm{kmol}^{23}$ Other amines not used in this work, such as piperazine, have been proposed. ${ }^{24,25}$ The use of other amines can be found in a review. ${ }^{26}$

Tables 2 and 3 shows the amines used in this work. Apart from ammonia, there are three primary amines (MEA, DGA, and AMP), a secondary amine (DEA), a tertiary amine (MDEA), and a mixed primary-secondary amine (DETA).

Primary amines seem to be more capable to capture $\mathrm{CO}_{2}$, while they have the highest reaction enthalpies, meaning that the regeneration operation will be conducted under strong

Table 2. Review of Regeneration Temperature and Heat Duties of MEA and DEA

\begin{tabular}{|c|c|c|c|}
\hline $\begin{array}{l}\text { temperature } \\
\left({ }^{\circ} \mathrm{C}\right)\end{array}$ & $\begin{array}{c}\text { heat duty } \\
(\mathrm{MJ} / \mathrm{kg} \mathrm{CO})_{2}\end{array}$ & details & $\begin{array}{c}\text { data } \\
\text { source }\end{array}$ \\
\hline \multicolumn{4}{|c|}{ MEA } \\
\hline 116.1 & 4.0 & $\begin{array}{l}30 \text { wt } \%, 0.25 \text { lean loading, } 0.478 \text { rich } \\
\text { loading, } 1.5 \text { bar }\end{array}$ & ref 8 \\
\hline 116.3 & 3.9 & $\begin{array}{l}30 \text { wt } \%, 0.25 \text { lean loading, } 0.481 \\
\text { rich loading, } 1.5 \text { bar }\end{array}$ & ref 10 \\
\hline 115.2 & 4.0 & $\begin{array}{l}30 \text { wt } \%, 0.25 \text { lean loading, } 0.477 \text { rich } \\
\text { loading, } 1.5 \text { bar }\end{array}$ & ref 10 \\
\hline 115.0 & 8.7 & 0.30 rich loading & ref 29 \\
\hline 115.0 & 6.5 & 0.35 rich loading & ref 29 \\
\hline 115.0 & 4.5 & 0.45 rich loading & ref 29 \\
\hline 130.0 & 12.0 & $\begin{array}{l}0.21 \text { lean loading, } 0.5 \text { rich loading (4 } \\
\left.\mathrm{kmol} / \mathrm{m}^{3}\right), 1 \mathrm{~atm}\end{array}$ & ref 30 \\
\hline 130.0 & 5.4 & $\begin{array}{l}0.22 \text { rich loading, } 0.5 \text { rich loading } \\
\left(4 \mathrm{~mol} / \mathrm{m}^{3}\right), 1 \mathrm{~atm}\end{array}$ & ref 30 \\
\hline 130.0 & 4.8 & $\begin{array}{l}0.26 \text { rich loading, } 0.5 \text { rich loading ( } 4 \\
\left.\mathrm{~mol} / \mathrm{m}^{3}\right), 1 \mathrm{~atm}\end{array}$ & ref 30 \\
\hline 130.0 & 3.8 & $\begin{array}{l}0.32 \text { lean loading, } 0.5 \text { rich loading } \\
\left(5 \mathrm{kmol} / \mathrm{m}^{3}\right), 1 \mathrm{~atm}\end{array}$ & ref 30 \\
\hline 120.0 & 4.3 & $\begin{array}{l}30 \text { wt } \%, 0.16 \text { lean loading, } 0.42 \text { rich } \\
\text { loading, } 2 \text { bar }\end{array}$ & ref 31 \\
\hline 112.0 & 4.55 & 30 wt $\%$ & ref 32 \\
\hline 112.0 & 3.36 & 30 wt $\%$, process improvement & ref 32 \\
\hline 120.0 & 3.98 & 30.3 wt $\%$ & ref 33 \\
\hline 126.7 & 4.01 & $\begin{array}{l}0.414 \text { lean loading, } 29.3 \mathrm{wt} \% \text { MEA, } \\
2.23 \text { bar }\end{array}$ & ref 16 \\
\hline 115.0 & 3.75 & $150 \mathrm{kPa}$ & ref 16 \\
\hline 133.0 & 3.45 & $275 \mathrm{kPa}$ & ref 16 \\
\hline 114.0 & 3.09 & $\begin{array}{l}0.30 \text { lean loading, } 0.477 \text { rich } \\
\text { loading, } 7 \text { mol } / \text { kgMEA ( } 30 \text { wt \%), } \\
1.7 \text { bar }\end{array}$ & ref 34 \\
\hline 71.6 & 16.0 & 20 wt $\%, 30 \mathrm{kPa}$ & ref 27 \\
\hline 83.8 & 11.0 & 20 wt $\%, 50 \mathrm{kPa}$ & ref 27 \\
\hline 94.3 & 9.0 & 20 wt $\%, 75 \mathrm{kPa}$ & ref 27 \\
\hline 114.1 & 6.75 & 20 wt $\%, 150 \mathrm{kPa}$ & ref 27 \\
\hline 123.0 & 5.1 & 20 wt $\%, 200 \mathrm{kPa}$ & ref 27 \\
\hline 130.0 & 4.7 & 20 wt $\%, 250 \mathrm{kPa}$ & ref 27 \\
\hline 136.0 & 4.4 & $\begin{array}{l}20 \text { wt } \%, 300 \mathrm{kPa} \\
\text { DEA }\end{array}$ & ref 27 \\
\hline 70.4 & 4.2 & 40 wt $\%, 30 \mathrm{kPa}$ & ref 27 \\
\hline 82.3 & 4.0 & 40 wt $\%, 50 \mathrm{kPa}$ & ref 27 \\
\hline 92.0 & 3.8 & 40 wt $\%, 75 \mathrm{kPa}$ & ref 27 \\
\hline 110.9 & 3.4 & 40 wt $\%, 150 \mathrm{kPa}$ & ref 27 \\
\hline 114.9 & 3.3 & 40 wt $\%, 175 \mathrm{kPa}$ & ref 27 \\
\hline 117.1 & 3.2 & 40 wt $\%, 200 \mathrm{kPa}$ & ref 27 \\
\hline 127.6 & 3.05 & 40 wt $\%, 300 \mathrm{kPa}$ & ref 27 \\
\hline- & 3.55 & 30 wt $\%$ & ref 35 \\
\hline- & 3.15 & 40 wt $\%$ & ref 35 \\
\hline- & 2.9 & 50 wt $\%$ & ref 35 \\
\hline- & 2.8 & $\begin{array}{l}0.447 \text { rich loading }\left(\mathrm{mol} \mathrm{CO}_{2} / \mathrm{mol}\right. \\
\text { DEA })\end{array}$ & ref 35 \\
\hline
\end{tabular}

Table 3. Review of Regeneration Temperature and Heat Duties of MDEA, DGA, AMP, DETA, and $\mathrm{NH}_{3}$

\begin{tabular}{|c|c|c|c|}
\hline $\begin{array}{l}\text { temperature } \\
\left({ }^{\circ} \mathrm{C}\right)\end{array}$ & $\begin{array}{c}\text { heat duty } \\
\left.(\mathrm{MJ} / \mathrm{kg} \mathrm{CO})_{2}\right)\end{array}$ & details & $\begin{array}{l}\text { data } \\
\text { source }\end{array}$ \\
\hline \multicolumn{4}{|c|}{ MDEA } \\
\hline 130.0 & 1.2 & $\begin{array}{l}0.06 \text { lean loading, } 0.5 \text { rich loading } \\
\left(4 \mathrm{kmol} / \mathrm{m}^{3} \text { solvent }\right), 1 \mathrm{~atm}\end{array}$ & ref 30 \\
\hline 130.0 & 2.8 & $\begin{array}{l}\text { 0.04 lean loading, } 0.5 \mathrm{rich} \text { loading } \\
\left(4 \mathrm{kmol} / \mathrm{m}^{3} \text { solvent }\right), 1 \mathrm{~atm}\end{array}$ & ref 30 \\
\hline 130.0 & 7.5 & $\begin{array}{l}0.03 \text { lean loading, } 0.5 \mathrm{rich} \text { loading } \\
\left(4 \mathrm{kmol} / \mathrm{m}^{3} \text { solvent }\right), 1 \mathrm{~atm}\end{array}$ & ref 30 \\
\hline 120.0 & 4.36 & $3 / 27$ wt $\%$ DEA/MDEA & ref 36 \\
\hline 112.9 & 3.82 & 30 wt $\%$ & ref 36 \\
\hline \multicolumn{4}{|c|}{ DGA } \\
\hline 85.8 & 4.5 & 60 wt $\%, 50 \mathrm{kPa}$ & ref 37 \\
\hline 96.5 & 4.1 & $60 \mathrm{wt} \%, 75 \mathrm{kPa}$ & ref 37 \\
\hline 110.9 & 3.2 & 60 wt $\%, 150 \mathrm{kPa}$ & ref 27 \\
\hline 116.0 & 2.9 & 60 wt $\%, 200 \mathrm{kPa}$ & ref 27 \\
\hline 120.7 & 2.8 & $60 \mathrm{wt} \%, 250 \mathrm{kPa}$ & ref 27 \\
\hline 124.1 & 2.7 & $\begin{array}{l}60 \text { wt } \%, 300 \mathrm{kPa} \\
\text { AMP }\end{array}$ & ref 27 \\
\hline 115.9 & 3.18 & 30 wt $\%$ & ref 36 \\
\hline 95.2 & 3.6 & $\begin{array}{l}5 / 25 \text { wt \% DEA/AMP } 0.41 \text { lean } \\
\text { loading, } 0.54 \text { rich loading }\end{array}$ & ref 17 \\
\hline 114.7 & 3.05 & $\begin{array}{l}5 / 25 \text { wt } \% \text { DEA/AMP } 0.07 \text { lean } \\
\text { loading, } 0.545 \text { rich loading }\end{array}$ & ref 17 \\
\hline 95.7 & 3.6 & $\begin{array}{l}10 / 20 \text { wt } \% \text { DEA/AMP } 0.43 \text { lean } \\
\text { loading, } 0.575 \text { rich loading }\end{array}$ & ref 17 \\
\hline 112.3 & 3.05 & $\begin{array}{l}\text { 10/20 wt \% DEA/AMP } 0.11 \text { lean } \\
\text { loading, } 0.548 \text { rich loading }\end{array}$ & ref 17 \\
\hline 95.2 & 3.8 & $\begin{array}{l}15 / 15 \text { wt \% DEA/AMP } 0.44 \text { lean } \\
\text { loading, } 0.568 \text { rich loading }\end{array}$ & ref 17 \\
\hline 114.6 & 3.1 & $\begin{array}{l}15 / 15 \text { wt } \% \text { DEA/AMP } 0.07 \text { lean } \\
\text { loading, } 0.541 \text { rich loading }\end{array}$ & ref 17 \\
\hline 115.0 & 9.2 & $\begin{array}{l}5 / 25 \text { wt } \% \text { PZ/AMP } 0.04 \text { lean } \\
\text { loading } 0.26 \text { rich loading }\end{array}$ & ref 38 \\
\hline 112.0 & 4.9 & $\begin{array}{l}\text { 5/25 wt \% PZ/AMP } 0.14 \text { lean } \\
\text { loading, } 0.28 \text { rich loading }\end{array}$ & ref 38 \\
\hline 110.0 & 4.6 & $\begin{array}{l}5 / 25 \text { wt } \% \text { PZ/AMP } 0.14 \text { lean } \\
\text { loading, } 0.28 \text { rich loading }\end{array}$ & ref 38 \\
\hline \multicolumn{4}{|c|}{ DETA } \\
\hline 100.0 & 4.8 & $\begin{array}{l}2 \mathrm{kmol} \text { DETA } / \mathrm{m}^{3}, 0.4 \text { cyclic } \\
\text { loading }\end{array}$ & ref 39 \\
\hline 100.0 & 2.2 & $\begin{array}{l}2 \mathrm{kmol} \mathrm{DETA} / \mathrm{m}^{3}, 0.56 \mathrm{cyclic} \\
\text { loading }\end{array}$ & ref 39 \\
\hline \multicolumn{4}{|c|}{$\mathrm{NH}_{3}$} \\
\hline 90.0 & 5.75 & 0.23 lean loading & ref 40 \\
\hline 131.0 & 2.53 & $\begin{array}{l}0.33 \text { lean loading, } 0.66 \text { rich loading, } \\
7.3 \text { wt } \% \mathrm{NH}_{3}, 10 \mathrm{bar}\end{array}$ & ref 41 \\
\hline 149.7 & 1.86 & $\begin{array}{l}10.2 \mathrm{wt} \% \mathrm{NH}_{3}, 0.236 \text { lean loading, } \\
0.41 \text { rich loading, } 12 \text { bar }\end{array}$ & ref 42 \\
\hline 145.5 & 3.27 & $\begin{array}{l}0.225 \text { lean loading, } 0.41 \text { rich } \\
\text { loading, } 10 \text { bar }\end{array}$ & ref 43 \\
\hline 145.5 & 2.46 & $\begin{array}{l}0.225 \text { lean loading, } 0.41 \text { rich } \\
\text { loading, process improvement, } 10 \\
\text { bar }\end{array}$ & ref 43 \\
\hline $110.0-139.0$ & $4-4.2$ & $\begin{array}{l}1.9-5.8 \text { wt } \% \mathrm{NH}_{3}, 0.21-0.41 \text { lean } \\
\text { loading }\end{array}$ & ref 44 \\
\hline
\end{tabular}

operating conditions. Several options for MEA are summarized in Table 2 . The heat duty ranges between $3.1 \mathrm{GJ} /$ ton $\mathrm{CO}_{2}$ and $16 \mathrm{GJ} /$ ton $\mathrm{CO}_{2}$, but it is usual does not exceed $5 \mathrm{GJ} /$ ton $\mathrm{CO}_{2}{ }^{27}$ Efforts to reduce this penalty have led to the use of other types of amines, such as DEA with a heat duty of 2.8-4.2 GJ/ton $\mathrm{CO}_{2}$ and regeneration temperatures of $70-130^{\circ} \mathrm{C}$. MDEA and DGA also show low regeneration energy requirements, with values of $2.8 \mathrm{GJ} /$ ton $\mathrm{CO}_{2}$ with usual stripper temperatures of 120-130 ${ }^{\circ} \mathrm{C}$, Table 3. Furthermore, DETA and AMP, that is a sterically 
hindered primary amine that produces unstable carbamates leading to easier regeneration than other primary amine carbamates although with reduced speed capture, ${ }^{28}$ exhibit low regeneration temperatures with heat duties in the range of 3.2-4.9 GJ/ton $\mathrm{CO}_{2}$.

\section{MODELING AND SIMULATION}

Simulations have been performed considering a Rankine cycle power plant that generates a gross of $500 \mathrm{MW}_{\mathrm{e}}$ with a net efficiency of $43.42 \%$. The boiler of the case-study power plant produces $353.0 \mathrm{~kg} / \mathrm{s}$ of steam at $300 \mathrm{bar}$ and $600{ }^{\circ} \mathrm{C}$. There is a single reheat at $620^{\circ} \mathrm{C}$. At nominal load, boiler steam output is $1073 \mathrm{MW}_{\mathrm{th}}$. Boiler efficiency is assumed as $92 \%$. Overall cycle data, electricity output, and efficiency estimations are summarized in Table 4. Figure 1 shows the flow diagram of

Table 4. Overall Cycle Data, Electricity Output, and Efficiency Estimations

\begin{tabular}{cccc}
\multicolumn{1}{c}{ parameter } & value & \multicolumn{1}{c}{ parameter } & value \\
$\begin{array}{c}\text { boiler energy } \\
\text { input } \\
\text { gross power } \\
\text { output } \\
\text { net power output }\end{array}$ & $1073 \mathrm{MW}_{\text {th }}$ & $\mathrm{CO}_{2}$ produced & $106.6 \mathrm{~kg} / \mathrm{s}$ \\
$\begin{array}{c}465.8 \mathrm{MW}_{\mathrm{e}} \\
\text { thermal energy }\end{array}$ & $\begin{array}{c}169.9 \\
\mathrm{LPH}\end{array}$ & $\begin{array}{c}\text { gross power plant } \\
\text { efficiency } \\
\text { net power plant } \\
\text { efficiency } \\
\text { thermal energy LPH }\end{array}$ & $46.70 \%$ \\
\hline
\end{tabular}

the power cycle. Live steam is expanded through nine turbine stages to a condenser pressure of 0.05 bar. Two high-pressure (HP) turbine stages operate between $600{ }^{\circ} \mathrm{C}$ and 300 bar at the inlet, and $320{ }^{\circ} \mathrm{C}$ and 50 bar at the outlet. Three mediumpressure (MP) turbine stages operate between $620^{\circ} \mathrm{C}$ and 45 bar at the inlet and $386^{\circ} \mathrm{C}$ and 10 bar at the outlet. Finally, five low-pressure (LP) turbine stages operate up to the condenser pressure. Four HP heaters, a deaerator, and five LP heaters are present. Table 5 shows the $m-P-T$ data corresponding to the flows shown in Figure 1.

Coal consumption and $\mathrm{CO}_{2}$ emissions have been calculated through a governmental report, ${ }^{45}$ using the average of coal low heating value $(\mathrm{LHV})$ for Spain $(22.40 \mathrm{GJ} / \mathrm{t}$ coal $)$ and its emission factor $\left(99.40 \mathrm{~kg} \mathrm{CO} / \mathrm{GJ}_{\mathrm{PCI}}\right)$. This represents a $\mathrm{CO}_{2}$ emission of $384.5 \mathrm{TCO}_{2} / \mathrm{h}(106.8 \mathrm{~kg} / \mathrm{s})$ at nominal power. This value is fixed for the comparative analysis and does not influence the solvent comparison.

Simulation of the power cycle is accomplished by means of EES (Engineering Equation Solver), and the following simplifying assumptions have been used:

- For the different stages of the HP, MP, and LP turbines: A constant isentropic efficiency, equal to 0.90 for HP stages, 0.92 for MP stages, and 0.90 for LP turbines, have been assumed. Since no partial load operation is evaluated, constant pressure bleeding in HP and IP turbines are considered. For the LP turbine, since the steam bleeding is influenced by the regeneration temperatures in the stripper, small pressure variations are allowed as it is explained.

- Regarding the pressure decrease in feedwater heaters, $2 \%$ inlet pressure at both steam and water sides is assumed. When amine scrubbing is considered, the extraction pressure is set by the steam temperature required in the stripper. The pressure is set whose saturation temperature is that of regeneration and a pressure decrease of $2 \%$ is taken into account.

- A terminal temperature difference (TTD) and the temperature drain cooler approach (TDCA) have been chosen for modeling the HP and LP heaters. They remain constant for the simulations: TTD values ranged between $3{ }^{\circ} \mathrm{C}$ and $4{ }^{\circ} \mathrm{C}$, and the values for TDCA are between $5{ }^{\circ} \mathrm{C}$ and $6{ }^{\circ} \mathrm{C}$, except in the second low-pressure heater (LPH2), which was set to $10^{\circ} \mathrm{C}$.

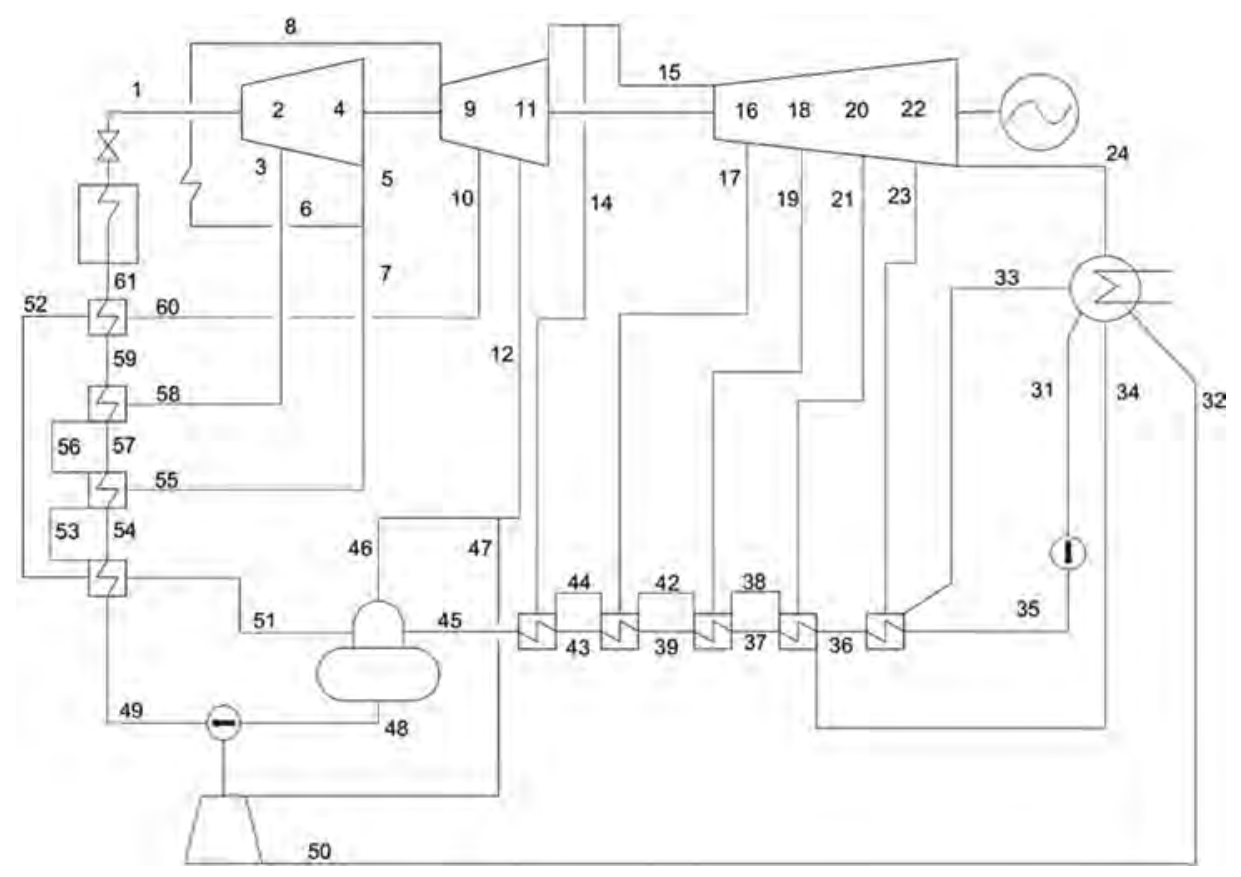

Figure 1. Layout of the Rankine steam cycle considered for simulations. 
Table 5. $m-P-T$ Data Corresponding to the Rankine Steam Cycle Shown in Figure 1

\begin{tabular}{|c|c|c|c|c|c|c|c|}
\hline stream & $m(\mathrm{~kg} / \mathrm{s})$ & $p$ (bar) & $t\left({ }^{\circ} \mathrm{C}\right)$ & stream & $m(\mathrm{~kg} / \mathrm{s})$ & $p$ (bar) & $t\left({ }^{\circ} \mathrm{C}\right)$ \\
\hline 1 & 353.00 & 300.00 & 600.0 & 33 & 16.02 & 0.29 & 39.4 \\
\hline 2 & 328.56 & 75.00 & 375.2 & 34 & 49.17 & 1.18 & 76.1 \\
\hline 3 & 24.44 & 75.00 & 375.2 & 35 & 281.48 & 20.91 & 33.4 \\
\hline 4 & 328.56 & 50.00 & 320.7 & 36 & 281.48 & 20.49 & 66.1 \\
\hline 5 & 328.56 & 50.00 & 320.7 & 37 & 281.48 & 20.08 & 101.3 \\
\hline 6 & 304.01 & 50.00 & 320.7 & 38 & 34.08 & 3.43 & 107.3 \\
\hline 7 & 24.56 & 50.00 & 320.7 & 39 & 281.48 & 19.68 & 135.9 \\
\hline 8 & 304.01 & 45.00 & 620.0 & 41 & 281.48 & 19.68 & 135.9 \\
\hline 9 & 296.44 & 29.00 & 545.7 & 42 & 18.85 & 5.88 & 140.9 \\
\hline 10 & 7.57 & 29.00 & 545.7 & 43 & 281.48 & 19.29 & 154.8 \\
\hline 11 & 266.30 & 18.00 & 470.7 & 44 & 10.08 & 9.90 & 160.8 \\
\hline 12 & 30.14 & 18.00 & 470.7 & 45 & 281.48 & 18.90 & 175.9 \\
\hline 13 & 266.30 & 10.00 & 386.1 & 46 & 14.96 & 18.00 & 470.7 \\
\hline 14 & 10.08 & 10.00 & 386.1 & 47 & 15.18 & 18.00 & 470.7 \\
\hline 15 & 256.22 & 10.00 & 386.1 & 48 & 353.00 & 18.52 & 208.5 \\
\hline 16 & 247.44 & 6.00 & 320.5 & 49 & 353.00 & 330.00 & 215.3 \\
\hline 17 & 8.77 & 6.00 & 320.5 & 50 & 15.18 & 0.05 & 32.1 \\
\hline 18 & 232.22 & 3.50 & 257.4 & 51 & 56.56 & 27.85 & 221.3 \\
\hline 19 & 15.23 & 3.50 & 257.4 & 52 & 7.57 & 28.42 & 293.5 \\
\hline 20 & 217.12 & 1.20 & 150.0 & 53 & 48.99 & 49.00 & 232.9 \\
\hline 21 & 15.09 & 1.20 & 150.0 & 54 & 353.00 & 326.70 & 226.9 \\
\hline 22 & 201.10 & 0.30 & 69.1 & 55 & 24.56 & 50.00 & 320.7 \\
\hline 23 & 16.02 & 0.30 & 69.1 & 56 & 24.44 & 73.50 & 265.7 \\
\hline \multirow[t]{2}{*}{24} & 201.10 & 0.05 & 32.9 & 57 & 353.00 & 323.43 & 259.7 \\
\hline & & & & 58 & 24.44 & 75.00 & 375.2 \\
\hline 31 & 281.48 & 0.05 & 32.9 & 59 & 353.00 & 320.20 & 287.5 \\
\hline 32 & 15.18 & 0.05 & 32.1 & 60 & 7.57 & 29.00 & 545.7 \\
\hline
\end{tabular}

The absorber pressure is assumed to be 1 bar for all cases. To supply the energy for the rich $\mathrm{CO}_{2}$ solvent regeneration, one LP steam bleeding is used. There are two main variables that determine the analysis. The required regeneration temperature fixes the pressure of the steam bleeding, and the required regeneration energy fixes the amount of steam mass flow needed in the steam turbine extraction. Steam bleeding pressures range from 0.3 bar of the last LP extraction before the condenser, to 10 bar of input to the LP turbine. Then, the regeneration temperature, which is the steam saturation temperature at these pressures, could range from $68.9^{\circ} \mathrm{C}$ to $179.5^{\circ} \mathrm{C}$. These values agree with regeneration requirements of the selected amines. Higher regeneration temperatures require an increase in steam bleeding pressure and, consequently, a reduction in the power produced by the turbine.

In this study, it is assumed that the third steam bleeding changes the pressure to adapt the stripper necessities. The fourth steam bleeding is not considered; it is a close bleeding. This due to the thermal energy of the $\mathrm{CO}_{2}$ compression intercooler that is used to preheat the water after the condenser. Temperature of the water after these heat exchangers is usually in the range of $89-132{ }^{\circ} \mathrm{C}$, which is well below the maximum temperature of the $\mathrm{CO}_{2}$ after compressors $\left(143-160{ }^{\circ} \mathrm{C}\right)$. These conditions make it technically feasible for a heat exchange with enough temperature difference. A new mixing heat exchanger is located instead of the $\mathrm{LPH} 2$, as shown in Figure 2. Water from the condenser, after being heated in $\mathrm{CO}_{2}$ compression intercoolers, is injected in this heat exchanger with the condensed water from the stripper and the condensed water from the third lowpressure heater (LPH3). When the regeneration temperature increases, the stripper pressure must be higher than the second low-pressure steam bleeding. In order to avoid any potential problem or unfair results comparison for all cases, the pressure of the second low-pressure steam bleeding is calculated as the average of the first (10 bar) and stripper (depending on the regeneration temperature) low-pressure steam bleeding.

Figure 2 illustrates the original layout of low-pressure heaters and two modified layouts to take into account the carbon capture installation and its integration in the power plant. In some cases, where the $\mathrm{CO}_{2}$ intercooling heat exceeds the capacity of the water to be heated, the remaining energy is integrated into the mixing heat exchanger after checking for any temperature limitation. This criterion is assumed to compare under the same assumptions (maximum heat recovery from $\mathrm{CO}_{2}$ intercooling) the different alternatives. For most of the cases, the first layout is analyzed when the required heat duty is $<3.5 \mathrm{MJ} /$ $\mathrm{kg} \mathrm{CO}$. For heat requirements of $>3.5 \mathrm{MJ} / \mathrm{kgCO}_{2}$ and high temperatures, both the pressure of the bleeding and the water through the low-pressure heaters limit the temperature difference in heat exchangers and the second steam bleeding also must be closed.

The $\mathrm{CO}_{2}$ compression scheme is simulated after that described in ref 46. Four $\mathrm{CO}_{2}$ compressor stages with intermediate intercooling and a pressure ratio of 3.23 are used to increase the pressure up to 120 bar. Each intercooler is divided into two heat exchangers. The first one reduces the $\mathrm{CO}_{2}$ temperature from the compressor outlet, in the range of 143$160^{\circ} \mathrm{C}$ to $60^{\circ} \mathrm{C}$. This is a useful heat stream that is integrated in the low-pressure part of the steam cycle, as shown in Figure 2. The second heat exchanger stage reduces the $\mathrm{CO}_{2}$ temperature from $60{ }^{\circ} \mathrm{C}$ to $30{ }^{\circ} \mathrm{C}$ to diminish the $\mathrm{CO}_{2}$ compressor power requirements. This heat stream is discarded and is released to the ambient environment. The isentropic efficiency of each $\mathrm{CO}_{2}$ compressor is assumed to be 0.8 . 

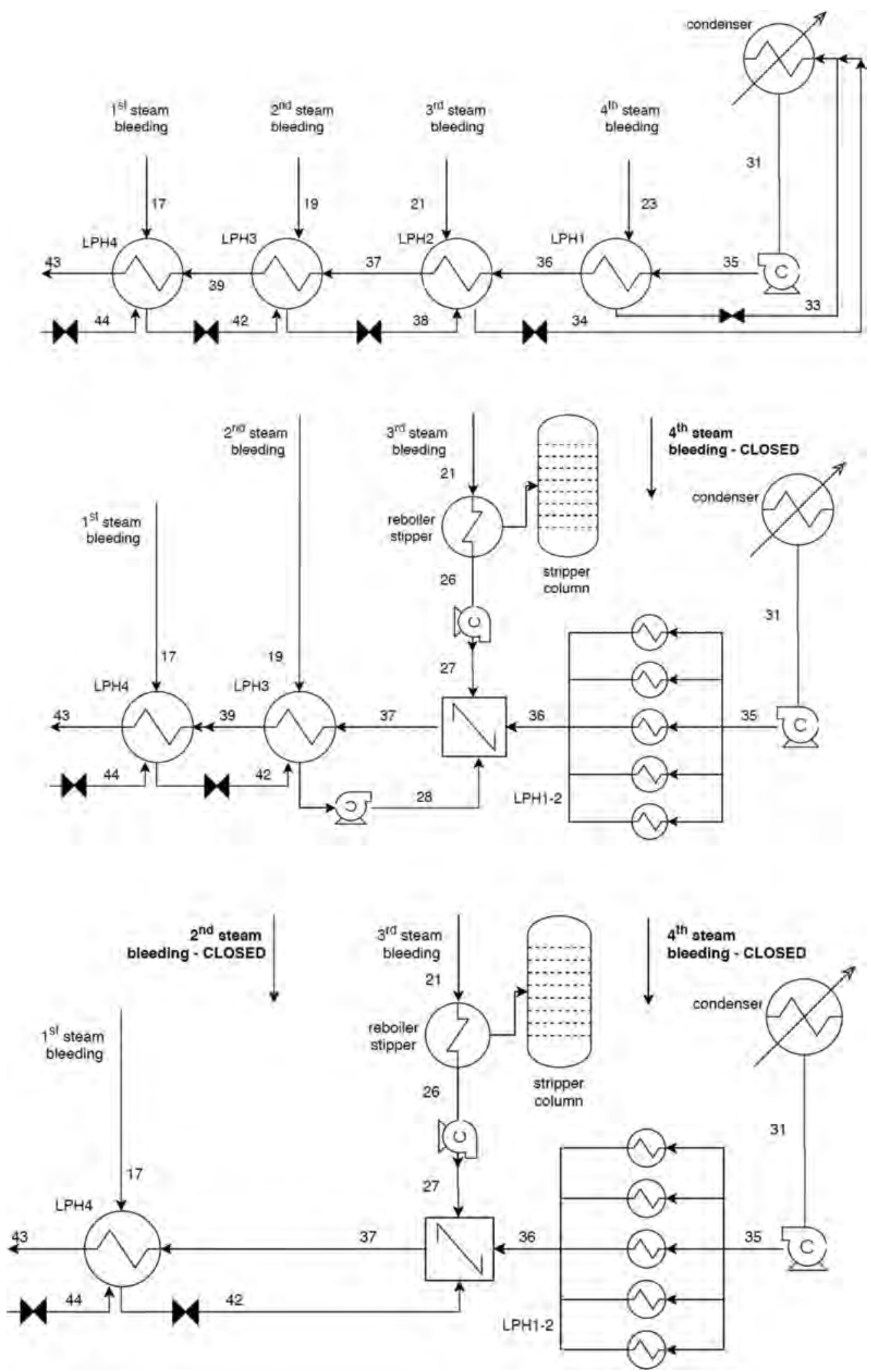

Figure 2. Original low-pressure heaters layout and modified layout with the carbon capture installation.

\section{RESULTS AND DISCUSSION}

\subsection{Effect of the Regeneration Temperature and} Stripper Heat Duty. First, a sensitivity analysis of the impact of regeneration temperature and heat duty shows how both variables influence the net global efficiency of the CCS power plant. The regeneration temperature is varied from $90^{\circ} \mathrm{C}$ to 160 ${ }^{\circ} \mathrm{C}$ and the heat duty is varied from 1.5 to $5.5 \mathrm{GJ} /$ ton $\mathrm{CO}_{2}$. Figure 3 illustrates the influence of the regeneration temperature at different heat duties, and Figure 4 shows the influence of the heat duty at different regeneration temperatures. 
Power plant net efficiency

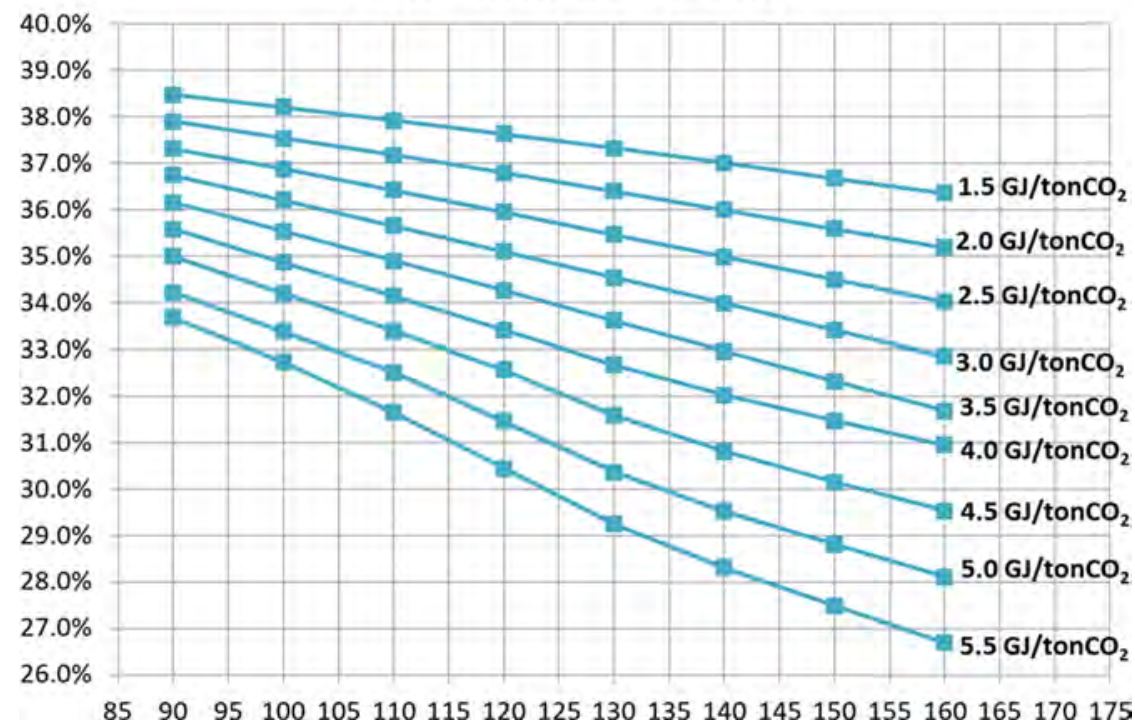

Figure 3. Influence of the regeneration temperature for different heat duties in the power plant net efficiency.

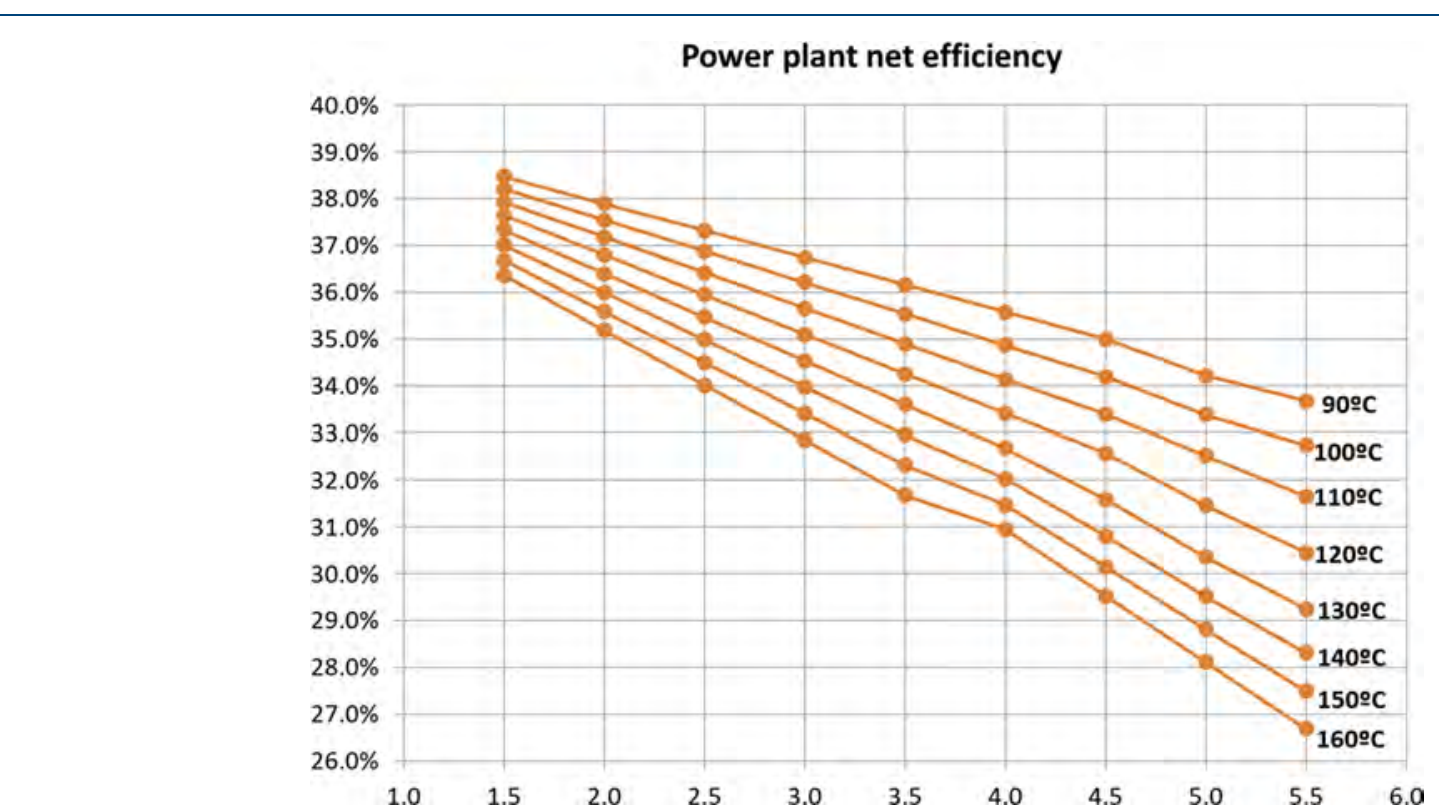

Figure 4. Influence of the heat duty for different regeneration temperatures in the power plant net efficiency.

With high regeneration temperatures, the steam bleeding pressure increases and, consequently, reduces the steam turbine power and net efficiency. It may also alter the design of the lowpressure heaters. The condensed steam from stripper recycled to the steam cycle has high temperatures and influences the layout of the low-pressure heaters.

For illustration purposes, when the heat duty and regeneration temperature are $3.0 \mathrm{MJ} / \mathrm{kg} \mathrm{CO}$ and $130{ }^{\circ} \mathrm{C}$, the heat required in the stripper ascends to $287.8 \mathrm{MW}_{\mathrm{th}}$, which is fulfilled with $123.16 \mathrm{~kg} / \mathrm{s}$ of steam at 2.7 bar. Steam bleedings (first, second, and third) are completely open. If the heat duty increases up to $5.5 \mathrm{MJ} / \mathrm{kg} \mathrm{CO}_{2}$ and $150{ }^{\circ} \mathrm{C}$, the heat required in the stripper increases to $479.7 \mathrm{MW}_{\mathrm{th}}$, which is fulfilled with $203.68 \mathrm{~kg} / \mathrm{s}$ of steam at $4.8 \mathrm{bar}$. For this reason, the second steam bleeding is not necessary and the contribution of the first steam bleeding is almost negligible. In this case, the temperature of stream 27 is high enough to make the heating of the condensate before deaerator unnecessary.

For a heat duty of $2.0 \mathrm{GJ} /$ ton $\mathrm{CO}_{2}$, the net efficiency range is $35.19 \%-37.90 \%$, and the values for regeneration temperatures are $160-190{ }^{\circ} \mathrm{C}$. For a heat duty of $5.0 \mathrm{GJ} /$ ton $\mathrm{CO}_{2}$, the net efficiency range is slightly higher between $28.11 \%$ and $34.22 \%$. The difference in efficiency penalty is close to 10 points, ranging from 7 points to $\sim 17$ points, when the heat duty to the stripper changes from 1.5 to $5.5 \mathrm{GJ} /$ ton $\mathrm{CO}_{2}$ for high regeneration temperatures $\left(160^{\circ} \mathrm{C}\right)$. Moreover, the value is $\sim 5$ points for regeneration temperatures of $90^{\circ} \mathrm{C}$. Taking into consideration stripper temperatures, the efficiency range for $90{ }^{\circ} \mathrm{C}$ is $33.68 \%$ and $38.48 \%$, and for $160{ }^{\circ} \mathrm{C}$ is $26.69 \%-36.36 \%$. The difference in efficiency is 9.7 points for the highest heat duty $(5.5 \mathrm{GJ} /$ ton $\mathrm{CO}_{2}$ ) and 4.8 points for the lowest heat duty of $1.5 \mathrm{GJ} /$ ton $\mathrm{CO}_{2}$. It is clear that the heat duty has more influence on the efficiency penalty in the power plants than the regeneration temperature, 


\section{Efficiency points penalty}

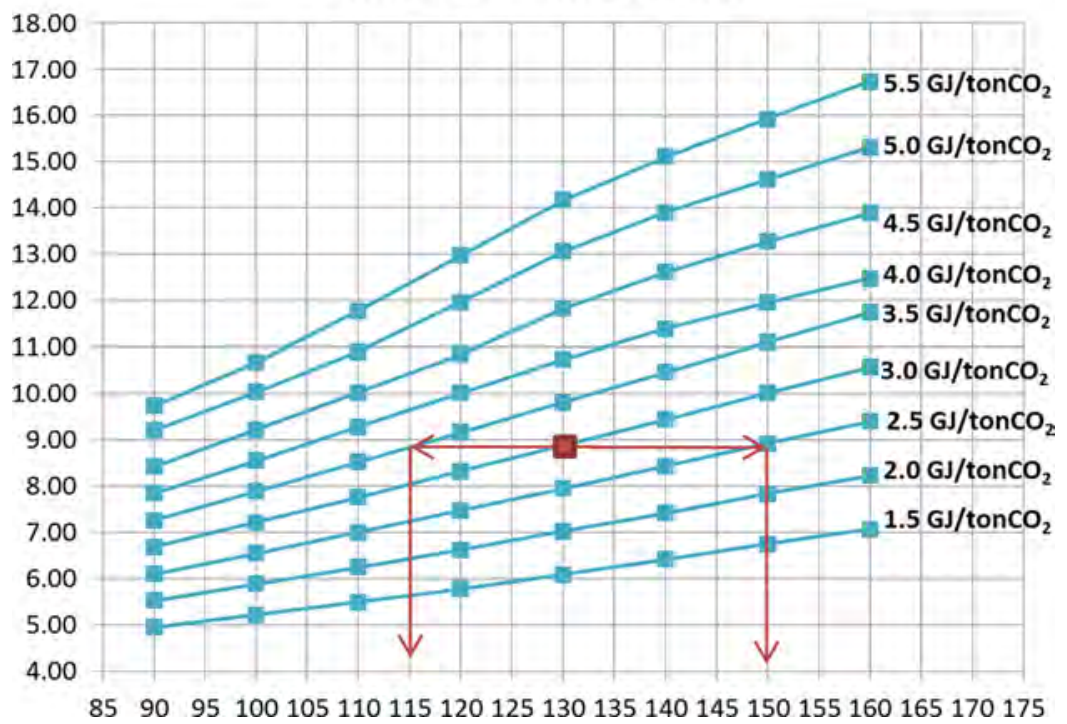

Figure 5. Net power plant efficiency, as a function of the regeneration temperature and heat duty in the amine regeneration.

Table 6. Solvents Selected To Perform the Energetic Comparison

\begin{tabular}{|c|c|c|c|c|}
\hline & temperature $\left({ }^{\circ} \mathrm{C}\right)$ & heat duty $\left(\mathrm{MJ} / \mathrm{kg} \mathrm{CO}{ }_{2}\right)$ & details & data source \\
\hline \multicolumn{5}{|c|}{ MEA } \\
\hline MEA1 & 116.3 & 3.9 & $30 \mathrm{wt} \%, 0.25$ lean loading, 0,481 rich loading, $1.5 \mathrm{bar}$ & ref 10 \\
\hline MEA2 & 130.0 & 5.4 & 0.22 rich loading, 0.5 rich loading $\left(4 \mathrm{kmol} / \mathrm{m}^{3}\right), 1 \mathrm{~atm}$ & ref 30 \\
\hline MEA3 & 130.0 & 3.8 & 0.32 lean loading, 0.5 rich loading $\left(5 \mathrm{kmol} / \mathrm{m}^{3}\right), 1 \mathrm{~atm}$ & ref 30 \\
\hline MEA4 & 120.0 & 4.3 & $30 \mathrm{wt} \%, 0.16$ lean loading, 0.42 rich loading, 2 bar & ref 31 \\
\hline MEA5 & 114.0 & 3.1 & $\begin{array}{l}0.30 \text { lean loading, } 0.477 \text { rich loading, } 7 \mathrm{~mol} / \mathrm{kg} \text { MEA ( } 30 \mathrm{wt} \%) \\
\text { DEA }\end{array}$ & ref 34 \\
\hline DEA & 110.9 & 3.4 & $\begin{array}{l}40 \mathrm{wt} \%, 150 \mathrm{kPa} \\
\text { MDEA }\end{array}$ & ref 27 \\
\hline MDEA1 & 130.0 & 2.8 & $\begin{array}{l}0.04 \text { lean loading, } 0.5 \text { rich loading }\left(4 \mathrm{kmol} / \mathrm{m}^{3} \text { solvent }\right), 1 \mathrm{~atm} \\
\text { DGA }\end{array}$ & ref 30 \\
\hline DGA1 & 96.5 & 4.1 & $60 \mathrm{wt} \%, 75 \mathrm{kPa}$ & ref 37 \\
\hline DGA2 & 120.7 & 2.8 & $\begin{array}{l}60 \mathrm{wt} \%, 250 \mathrm{kPa} \\
\text { AMP }\end{array}$ & ref 27 \\
\hline AMP1 & 95.2 & 3.8 & 15/15 wt \% DEA/AMP 0.44 lean loading, 0.568 rich loading & ref 17 \\
\hline AMP2 & 112.0 & 4.9 & $\begin{array}{l}\text { 5/25 wt \% PZ/AMP } 0.14 \text { lean loading, } 0.28 \text { rich loading } \\
\text { DETA }\end{array}$ & ref 38 \\
\hline DETA & 100.0 & 4.8 & $2 \mathrm{kmol} \mathrm{DETA} / \mathrm{m}^{3}, 0,4$ cyclic loading & ref 39 \\
\hline
\end{tabular}

but this last influence is also remarkable. The effect on the net efficiency of increasing the heat duty by $1 \mathrm{GJ} /$ ton $\mathrm{CO}_{2}$ is similar to the reduction between $40^{\circ} \mathrm{C}$ (for $1.5 \mathrm{GJ} /$ ton $\mathrm{CO}_{2}$ ) and $20^{\circ} \mathrm{C}$ (for $4.5 \mathrm{GJ} /$ ton $\mathrm{CO}_{2}$ ) of the regeneration temperature.

As Figure 5 shows, for a heat duty of $3.0 \mathrm{GJ} /$ ton $\mathrm{CO}_{2}$ at a regeneration temperature of $130{ }^{\circ} \mathrm{C}$, the penalty into the power plant is 8.9 efficiency points. A similar penalty is also caused by a solvent with a heat duty of $3.5 \mathrm{GJ} /$ ton $\mathrm{CO}_{2}$ and a regeneration temperature of $\sim 115^{\circ} \mathrm{C}$, and with a solvent of a heat duty of 2.5 $\mathrm{GJ} /$ ton $\mathrm{CO}_{2}$ and a regeneration temperature of $>150{ }^{\circ} \mathrm{C}$. In this last case, even with lower heat duty, if the regeneration temperature is high, the integration possibilities decrease, and some of the low-grade heat must be discarded to condensers in some cases.

The effect of high regeneration temperatures is more critical when combined with high heat duties. When regeneration requirements are high, the steam bleeding to stripper increases, and a small fraction of the steam drives the LP turbine and goes into the condenser. Since the condenser stream is small, the most of the $\mathrm{CO}_{2}$ intercooler heat must be used together with the mixing heat exchanger as the stream temperature of $36{ }^{\circ} \mathrm{C}$ is limited by the $\mathrm{CO}_{2}$ maximum temperature after compressors. This causes that the stream temperature of $37^{\circ} \mathrm{C}$ would be high enough to make the steam bleeding (19) and even (17) useless (see Figure 1), because of the high condensate temperature. This effect is observed with a heat duty of $>4.0 \mathrm{GJ} /$ ton $\mathrm{CO}_{2}$ when the temperature is $>150{ }^{\circ} \mathrm{C}$. When the heat duty increases to $>5.0 \mathrm{GJ} /$ ton $\mathrm{CO}_{2}$, the steam bleeding is closed for the all temperature ranges.

When the regeneration temperature is high, the temperature of stream 37 should be limited to maintain a suitable temperature difference in $\mathrm{CO}_{2}$ intercoolers and mixing heat exchangers. Then, part of the intercooling heat must be thrown away. In these cases, efficiency decreases because of the discarded energy. It happens for a heat duty of $5.5 \mathrm{GJ} / \mathrm{ton}$ $\mathrm{CO}_{2}$ and temperatures of $>120^{\circ} \mathrm{C}$, for a heat duty of $5.0 \mathrm{GJ} /$ ton 


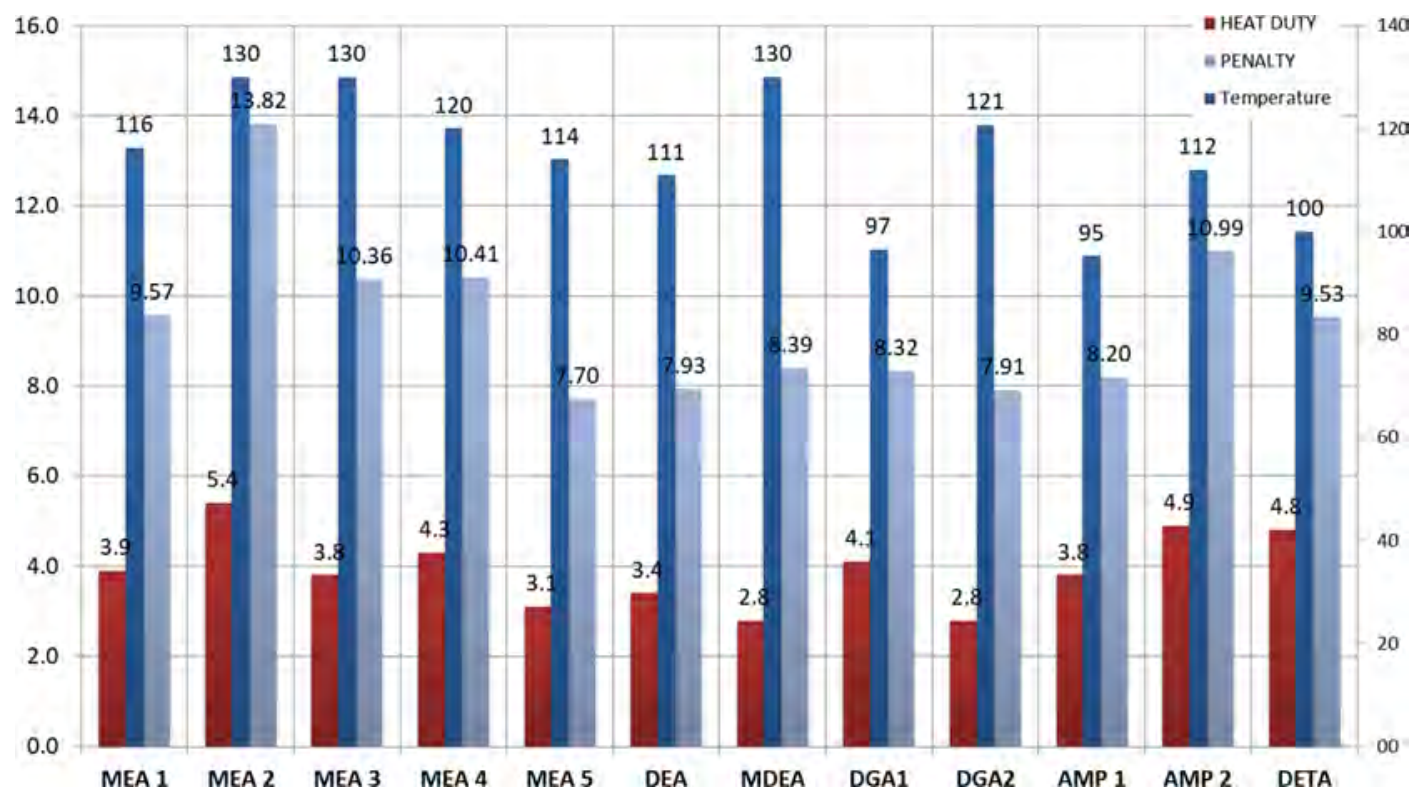

Figure 6. Net power plant efficiency as a function of the regeneration temperature and heat duty in the amine regeneration.

$\mathrm{CO}_{2}$ and temperatures of $>130^{\circ} \mathrm{C}$, and for heat duties of $4.0-$ $4.5 \mathrm{GJ} /$ ton $\mathrm{CO}_{2}$ and temperatures of $>140{ }^{\circ} \mathrm{C}$. It is illustrated in Figure 5 as the slope of the high heat duties increases more than in the case of low heat duties.

4.2. Energy Comparison of Different Solvents for $\mathrm{CO}_{2}$ Capture. Table 6 illustrates the comparison of the selected solvents shown in bold in Tables 2 and 3. There are five solvents based on MEA: one on DEA and MDEA, two on DGA, two on AMP, and one on DETA. Different regeneration energy requirements and temperatures have been selected. Ammonia has not been taken into consideration; it requires different energy integration and additional assumptions should be made to perform the comparison.

Simulations have been performed by using the following parameters as inputs: the stripper heat duty, regeneration temperature, amine concentration in the dissolution, and lean and rich amine loading. Results include the impact on the steam cycle streams and, as a consequence, the calculation of the power plant net efficiency and efficiency point losses. The general trend of the results is in agreement with the previous figures. In this case, the quantification of the impact in efficiency is the most important outcome.

For MEA, regeneration temperatures are between $110^{\circ} \mathrm{C}$ and $130{ }^{\circ} \mathrm{C}$ and heat duties range from $3.1 \mathrm{GJ} /$ ton $\mathrm{CO}_{2}$ to $5.4 \mathrm{GJ} /$ ton $\mathrm{CO}_{2}$. Results are in agreement with some references. ${ }^{47}{ }^{50}$ In this solvent, as Figure 6 illustrates, the effect on efficiency loss varies between 7.7 and 13.82 points. Differences between MEA1 and MEA3 are mainly caused by temperature and the effect on efficiency is relatively small ( 10.36 points for $130{ }^{\circ} \mathrm{C}$ and 9.57 points for $116{ }^{\circ} \mathrm{C}$ ). However, for MEA2 and MEA3, the deviation is caused by the difference in heat duty and a gap of 3.46 efficiency points is observed.

In the case of DEA, the results are significantly good with low efficiency penalty, similar to MEA with the lowest heat duty and temperature. The cases of MDEA and DGA also show good results with efficiency losses of $\sim 8$ points. In these cases, the heat duty is low, compared to that for MEA $\left(2.8 \mathrm{GJ} /\right.$ ton $\left.\mathrm{CO}_{2}\right)$, and, in the case of comparable requirements, the regeneration temperature $\left(96.5^{\circ} \mathrm{C}\right)$ is much lower than the $130^{\circ} \mathrm{C}$ observed for MEA.
The cases selected for AMP that are blended with DEA and PZ in different proportions ${ }^{1738}$ do not have evidence of improved results, even if a low stripper temperature is necessary for AMP1. Finally, the case of DETA is in agreement with the general trend and shows better results than AMP2 (similar heat duty) caused by a lower temperature required.

\section{CONCLUSIONS}

There are many possible solvents for $\mathrm{CO}_{2}$ capture based on amine scrubbing. A common feature is the high energy requirements in the regeneration step. Two main variables define the energy necessities: the heat duty and the regeneration temperature. A literature review shows different values for these variables, and it is difficult to know and isolate the independent effect of each variable on the net effect of energy requirements of the carbon capture.

A comparison under the same set of assumptions of the effect in net power plant efficiency of heat duty and regenerations temperatures in the stripper of amine scrubbing for $\mathrm{CO}_{2}$ capture has been presented. Results show that efficiency points penalty ranges between 7 for a heat duty of $1.5 \mathrm{GJ} /$ ton $\mathrm{CO}_{2}$ and regeneration temperature of $90{ }^{\circ} \mathrm{C}$ to $\sim 17$ points for a heat duty of $5.5 \mathrm{GJ} /$ ton $\mathrm{CO}_{2}$ and regeneration temperature of $160^{\circ} \mathrm{C}$. The effect on efficiency is more important for higher heat duties, and steam cycle modification should be done to use as much waste energy from $\mathrm{CO}_{2}$ intercooling and steam turbine bleeding as possible. The effect of a net efficiency increase of $1 \mathrm{GJ} /$ ton $\mathrm{CO}_{2}$ on the heat duty is similar to the reduction in the regeneration temperature between $40{ }^{\circ} \mathrm{C}$ (for $1.5 \mathrm{GJ} /$ ton $\mathrm{CO}_{2}$ ) and $20{ }^{\circ} \mathrm{C}$ (for $4.5 \mathrm{GJ} /$ ton $\mathrm{CO}_{2}$ ).

For the amines, the impact in efficiency points varies between 7.70 for MEA5 and 13.82 for MEA2. This is mainly caused by the difference in heat duty $\left(3.1 \mathrm{GJ} /\right.$ ton $\mathrm{CO}_{2}$ vs $5.4 \mathrm{GJ} /$ ton $\left.\mathrm{CO}_{2}\right)$, as well as regeneration temperature $\left(114^{\circ} \mathrm{C}\right.$ vs $\left.130^{\circ} \mathrm{C}\right)$. There are several options (MEA5, DEA, MDEA, DGA1, DGA2, AMD1) that show that achieving an efficiency reduction of $\sim 8$ points is possible. It is important to highlight that these conclusions only show the results of an energy analysis. It is evident that, in the utilization of these amines for carbon 
capture, there are other limitations that can affect a complete techno-economic feasibility study.

\section{ASSOCIATED CONTENT}

\section{Special Issue Paper}

Originally intended for the special issue Carbon Capture and Utilization, Ind. Eng. Chem. Res. 2020, Volume 59, Issue 15.

\section{AUTHOR INFORMATION}

\section{Corresponding Author}

Luis M. Romeo - Escuela de Ingenieria y Arquitectura,

Departamento de Ingenieria Mecánica, Universidad de Zaragoza, 50018 Zaragoza, Spain; 이이.org/0000-0001-7379-6159; Email: luismi@unizar.es

\section{Authors \\ Diego Minguell - Escuela de Ingenieria y Arquitectura, Departamento de Ingeniería Mecánica, Universidad de Zaragoza, 50018 Zaragoza, Spain \\ Reza Shirmohammadi - Escuela de Ingenieria y Arquitectura, Departamento de Ingenieria Mecánica, Universidad de Zaragoza, 50018 Zaragoza, Spain; Faculty of New Sciences \& Technologies, University of Tehran, Tehran, Iran \\ José M. Andrés - Instituto de Carboquimica-CSIC, Zaragoza 50018, Spain}

Complete contact information is available at:

https://pubs.acs.org/10.1021/acs.iecr.0c01483

\section{Notes}

The authors declare no competing financial interest.

\section{ACKNOWLEDGMENTS}

The work described in this paper is supported by the Government of Aragon and cofinanced by FEDER 2014-2020 "Construyendo Europa desde Aragón” (Research Group DGA T46_17R).

\section{REFERENCES}

(1) Moustakas, K.; Loizidou, M.; Rehan, M.; Nizami, A. S. A review of recent developments in renewable and sustainable energy systems: Key challenges and future perspective. Renewable Sustainable Energy Rev. 2020, 119, 109418

(2) Bui, M.; Adjiman, C. S.; Bardow, A.; Anthony, E. J.; Boston, A.; Brown, S.; et al. Carbon capture and storage (CCS): the way forward. Energy Environ. Sci. 2018, 11, 1062.

(3) Liang, Z.; Rongwong, W.; Liu, H.; Fu, K.; Gao, H.; Cao, F.; Zhang, R.; Sema, T.; Henni, A.; Sumon, K.; et al. Recent progress and new developments in post-combustion carbon-capture technology with amine based solvents. Int. J. Greenhouse Gas Control 2015, 40, 26-54.

(4) Barzagli, F.; Giorgi, C.; Mani, F.; Peruzzini, M. Reversible carbon dioxide capture by aqueous and non-aqueous amine-based absorbents: A comparative analysis carried out by ${ }^{13} \mathrm{C}$ NMR spectroscopy. Appl. Energy 2018, 220, 208-19.

(5) Law, L. C.; Yusoff Azudin, N.; Rizal Abd. Shukor, S. Optimization and economic analysis of amine-based acid gas capture unit using monoethanolamine/methyl diethanolamine. Clean Technol. Environ. Policy 2018, 20, 451-461.

(6) Nwaoha, C.; Beaulieu, M.; Tontiwachwuthikul, P.; Gibson, M. D. Techno-economic analysis of CO2 capture from a 1.2 million MTPA cement plant using AMP-PZ-MEA blend. Int. J. Greenhouse Gas Control 2018, 78, 400-12.

(7) Shirmohammadi, R.; Soltanieh, M.; Romeo, L. M. Thermoeconomic analysis and optimization of post-combustion $\mathrm{CO} 2$ recovery unit utilizing absorption refrigeration system for a natural-gas-fired power plant. Environ. Prog. Sustainable Energy 2018, 37, 1075-1084.
(8) Xue, B.; Yu, Y.; Chen, J.; Luo, X.; Wang, M. A comparative study of MEA and DEA for post-combustion $\mathrm{CO} 2$ capture with different process configurations. Int. J. Coal Sci. Technol. 2017, 4, 15-24.

(9) Frimpong, R. A.; Johnson, D.; Richburg, L.; Hogston, B.; Remias, J. E.; Neathery, J. K.; et al. Comparison of solvent performance for CO2 capture from coal-derived flue gas: A pilot scale study. Chem. Eng. Res. Des. 2013, 91, 963-9.

(10) Zhang, X.; Huang, Y.; Gao, H.; Luo, X.; Liang, Z.; Tontiwachwuthikul, P. Zeolite catalyst-aided tri-solvent blend amine regeneration: An alternative pathway to reduce the energy consumption in amine-based $\mathrm{CO} 2$ capture process. Appl. Energy 2019, 240, 827-41.

(11) Wang, L.; Zhang, Y.; Wang, R.; Li, Q.; Zhang, S.; Li, M.; et al. Advanced Monoethanolamine Absorption Using Sulfolane as a Phase Splitter for CO2 Capture. Environ. Sci. Technol. 2018, 52, 14556-63.

(12) Lin, P. H.; Wong, D. S. H. Carbon dioxide capture and regeneration with amine/alcohol/water blends. Int. J. Greenhouse Gas Control 2014, 26, 69-75.

(13) Lee, A. S.; Eslick, J. C.; Miller, D. C.; Kitchin, J. R. Comparisons of amine solvents for post-combustion $\mathrm{CO} 2$ capture: A multi-objective analysis approach. Int. J. Greenhouse Gas Control 2013, 18, 68-74.

(14) Gervasi, J.; Dubois, L.; Thomas, D. Simulation of the postcombustion $\mathrm{CO}_{2}$ capture with Aspen Hysys software: Study of different configurations of an absorptionregeneration process for the application to cement flue gases. Energy Procedia 2014, 63, 1018-1028.

(15) Øi, L. E. Aspen HYSYS Simulation of $\mathrm{CO}_{2}$ Removal by Amine Absorption from a Gas Based Power Plant. Presented at the SIMS2007 Conference, Gøteborg, Sweden, 2007.

(16) Li, K.; Cousins, A.; Yu, H.; Feron, P.; Tade, M.; Luo, W. Systematic study of aqueous monoethanolamine-based $\mathrm{CO}_{2}$ capture process: Model development and process improvement. Energy Sci. Eng. 2016, 4, 23.

(17) Adeosun, A.; Abu-Zahra, M. R. M. Evaluation of amine-blend solvent systems for $\mathrm{CO}_{2}$ post-combustion capture applications. Energy Procedia 2013, 37, 211.

(18) Dubois, L.; Thomas, D. Comparison of various configurations of the absorption-regeneration process using different solvents for the post-combustion $\mathrm{CO}_{2}$ capture applied to cement plant flue gases. Int. J. Greenhouse Gas Control 2018, 69, 20-35.

(19) Jilvero, H.; Normann, F.; Andersson, K.; Johnsson, F. Heat requirement for regeneration of aqueous ammonia in post-combustion carbon dioxide capture. Int. J. Greenhouse Gas Control 2012, 11, 181.

(20) Hikita, H.; Asai, S.; Katsu, Y.; Ikuno, S. Absorption of carbon dioxide into aqueous monoethanolamine solutions. AIChE J. 1979, 25, 793-800.

(21) Sada, E.; Kumazawa, H.; Butt, M. A. Gas absorption with consecutive chemical reaction: Absorption of carbon dioxide into aqueous amine solutions. Can. J. Chem. Eng. 1976, 54, 421-4.

(22) Rho, S.-W.; Yoo, K.-P.; Lee, J. S.; Nam, S. C.; Son, J. E.; Min, B.M. Solubility of CO 2 in Aqueous Methyldiethanolamine Solutions. J. Chem. Eng. Data 1997, 42, 1161-4.

(23) Hartono, A.; da Silva, E. F.; Svendsen, H. F. Kinetics of carbon dioxide absorption in aqueous solution of diethylenetriamine (DETA). Chem. Eng. Sci. 2009, 64, 3205.

(24) Bishnoi, S.; Rochelle, G. T. Absorption of carbon dioxide into aqueous piperazine: Reaction kinetics, mass transfer and solubility. Chem. Eng. Sci. 2000, 55, 5531-43.

(25) Bishnoi, S.; Rochelle, G. T. Absorption of carbon dioxide in aqueous piperazine/methyldiethanolamine. AIChE J. 2002, 48, 278899.

(26) Yu, C. H.; Huang, C. H.; Tan, C. S. A review of $\mathrm{CO}_{2}$ capture by absorption and adsorption. Aerosol Air Qual. Res. 2012, 12, 745-69.

(27) Warudkar, S. S.; Cox, K. R.; Wong, M. S.; Hirasaki, G. J. Influence of stripper operating parameters on the performance of amine absorption systems for post-combustion carbon capture: Part II. Vacuum strippers. Int. J. Greenhouse Gas Control 2013, 16, 342-50.

(28) Xiao, J.; Li, C.-W.; Li, M.-H. Kinetics of absorption of carbon dioxide into aqueous solutions of 2-amino-2-methyl-1-propanol +monoethanolamine. Chem. Eng. Sci. 2000, 55, 161-75. 
(29) Brúder, P.; Owrang, F.; Svendsen, H. F. Pilot study-CO $\mathrm{CO}_{2}$ capture into aqueous solutions of 3-methylaminopropylamine (MAPA) activated dimethyl-monoethanolamine (DMMEA). Int. J. Greenhouse Gas Control 2012, 11, 98.

(30) Sakwattanapong, R.; Aroonwilas, A.; Veawab, A. Behavior of reboiler heat duty for $\mathrm{CO}_{2}$ capture plants using regenerable single and blended alkanolamines. Ind. Eng. Chem. Res. 2005, 44, 4465.

(31) Geuzebroek, F. H.; Schneiders, L. H. J. M.; Kraaijveld, G. J. C.; Feron, P. H. M. Exergy analysis of alkanolamine-based $\mathrm{CO}_{2}$ removal unit with AspenPlus. Energy 2004, 29, 1241-1248.

(32) Wang, B.; Jin, H.; Zheng, D. Recovery of $\mathrm{CO}_{2}$ with MEA and K2CO3 absorption in the IGCC system. Int. J. Energy Res. 2004, 28, 521.

(33) Notz, R.; Mangalapally, H. P.; Hasse, H. Post combustion $\mathrm{CO}_{2}$ capture by reactive absorption: Pilot plant description and results of systematic studies with MEA. Int. J. Greenhouse Gas Control 2012, 6, 84.

(34) Rezazadeh, F.; Gale, W. F.; Lin, Y. J.; Rochelle, G. T. Energy Performance of Advanced Reboiled and Flash Stripper Configurations for $\mathrm{CO}_{2}$ Capture Using Monoethanolamine. Ind. Eng. Chem. Res. 2016, 55,4622 .

(35) Xue, B., Yu, Y., Chen, J.. Process Simulation and Energy Consumption Analysis for $\mathrm{CO}_{2}$ Capture with Different Solvents. In Exergy for A Better Environment and Improved Sustainability, Vol. 2; Alou, F., Dincer, I., Eds.; Springer, 2018; pp 25-45.

(36) Dave, N.; Do, T.; Puxty, G.; Rowland, R.; Feron, P. H. M.; Attalla, M. I. $\mathrm{CO}_{2}$ capture by aqueous amines and aqueous ammonia-A Comparison. Energy Procedia 2009, 1, 949.

(37) Warudkar, S. S.; Cox, K. R.; Wong, M. S.; Hirasaki, G. J. Influence of stripper operating parameters on the performance of amine absorption systems for post-combustion carbon capture: Part I. High pressure strippers. Int. J. Greenhouse Gas Control 2013, 16, 342.

(38) Artanto, Y.; Jansen, J.; Pearson, P.; Puxty, G.; Cottrell, A.; Meuleman, E. Pilot-scale evaluation of AMP/PZ to capture $\mathrm{CO}_{2}$ from flue gas of an Australian brown coal-fired power station. Int. J. Greenhouse Gas Control 2014, 20, 189.

(39) Zhang, X.; Fu, K.; Liang, Z.; Rongwong, W.; Yang, Z.; Idem, R. Experimental studies of regeneration heat duty for $\mathrm{CO}_{2}$ desorption from diethylenetriamine (DETA) solution in a stripper column packed with Dixon ring random packing. Fuel 2014, 136, 261.

(40) Zhang, M.; Guo, Y. Process simulations of large-scale $\mathrm{CO}_{2}$ capture in coal-fired power plants using aqueous ammonia solution. Int. J. Greenhouse Gas Control 2013, 16, 61.

(41) Darde, V.; Maribo-Mogensen, B.; van Well, W. J. M.; Stenby, E. $\mathrm{H}$.; Thomsen, K. Process simulation of $\mathrm{CO}_{2}$ capture with aqueous ammonia using the Extended UNIQUAC model. Int. J. Greenhouse Gas Control 2012, 10, 74.

(42) Jiang, K.; Li, K.; Yu, H.; Chen, Z.; Wardhaugh, L.; Feron, P. Advancement of ammonia based post-combustion $\mathrm{CO}_{2}$ capture using the advanced flash stripper process. Appl. Energy 2017, 202, 496.

(43) Li, K.; Yu, H.; Feron, P.; Tade, M.; Wardhaugh, L. Technical and Energy Performance of an Advanced, Aqueous Ammonia-Based $\mathrm{CO}_{2}$ Capture Technology for a $500 \mathrm{MW}$ Coal-Fired Power Station. Environ. Sci. Technol. 2015, 49, 10243.

(44) Yu, H.; Morgan, S.; Allport, A.; Cottrell, A.; Do, T.; McGregor, J.; Wardhaugh, L.; Feron, P. Results from trialling aqueous $\mathrm{NH}_{3}$ based post combustion capture in a pilot plant at Munmorah power station: Desorption. Chem. Eng. Res. Des. 2011, 89, 1204-1215.

(45) Ministerio para la transicion ecológica. Factores de emisión. Registro de huella de carbono, compensacion y proyectos de absorción de dioxido de carbono, 2019, https://www.miteco.gob.es/es/cambioclimatico/temas/mitigacion-politicas-y-medidas/registro-huella.aspx.

(46) Romeo, L. M.; Bolea, I.; Lara, Y.; Escosa, J. M. Optimization of intercooling compression in $\mathrm{CO}_{2}$ capture systems. Appl. Therm. Eng. 2009, 29, 1744.

(47) Goto, K.; Chowdhury, A.; Yamada, H.; Higashii, T. Potential of Amine-based Solvents for Energy-saving CO2 Capture from a Coalfired Power Plant. J. Japan Inst Energy 2016, 95, 1133-41.

(48) Veneman, R.; Kamphuis, H.; Brilman, D. W. F. Post-Combustion $\mathrm{CO} 2$ capture using supported amine sorbents: A process integration study Selection and/or peer-review under responsibility of GHGT. Energy Procedia 2013, 37, 2100-8.

(49) Romeo, L. M.; Espatolero, S.; Bolea, I. Designing a supercritical steam cycle to integrate the energy requirements of $\mathrm{CO} 2$ amine scrubbing. Int. J. Greenhouse Gas Control 2008, 2, 563-70.

(50) Le Moullec, Y.; Kanniche, M. Optimization of MEA based post combustion $\mathrm{CO}_{2}$ capture process: Flowsheeting and energetic integration. Energy Procedia 2011, 4, 1303-1309. 